\title{
Performance Analysis of a New Waste Heat Recovery System
}

\author{
Saed A. Musmar ${ }^{a, *}$, Nasim Razavinia $^{b}$, Frank Mucciardi $^{b}$, Iskander Tlili $^{c}$ \\ ${ }^{a}$ Department of Industrial Engineering, Faculty of Engineering and Technology, University of Jordan, Amman, Jordan \\ ${ }^{b}$ Materials and Metallurgical Department, McGill University, Montreal, Canada \\ ${ }^{c}$ Mechanical Engineering Department, Engineering College, Majmaah University. Kingdom of Saudi Arabia
}

\begin{abstract}
The overall theme of this research is to capture, concentrate and convert some of the waste heat generated at industrial plants to a valuable form of energy. A new system for heat recovery from low grade energy has been built and tested based on a modified heat pipe technology. A single heat pipe used in this research was able to extract $2 \mathrm{~kW}$ of energy from waste heat of $250{ }^{\circ} \mathrm{C}$. However a heat pipe can extract $11.5 \mathrm{~kW} / \mathrm{m}^{2}$ heat fluxes. The maximum energy extraction by such system from low grad energy can be up to $3 \mathrm{~kW}$. While a heat pipe regardless of its size can have heat flux up to $16.5 \mathrm{~kW} / \mathrm{m}^{2}$ from waste heat flow at $250{ }^{\circ} \mathrm{C}$ and $12.3 \mathrm{~m} / \mathrm{s}$ velocity. Also, the system can extract about $1 \mathrm{~kW}$ heat or $6.5 \mathrm{~kW} / \mathrm{m} 2 \mathrm{heat}$ flux at temperatures as low as $150{ }^{\circ} \mathrm{C}$. However, the system doesn't function properly at temperatures lower than $150{ }^{\circ} \mathrm{C}$.
\end{abstract}

Keywords: Waste heat recovery, Latent heat, Heat pipe, Vortex promoters, thermal conveying

\section{Introduction}

In industrial processes, there are many low-temperature waste heat sources $\left(<230^{\circ} \mathrm{C}\right)$ which cannot be effectively recovered by simple heat exchanger devices. The Organic Rankine Cycle (ORC) heat engine has a high potential to convert them into power (Fig. 1), since some organic fluids have suitable thermodynamic properties, such as low boiling point and medium vapor pressure at a moderate temperature, and low isentropic turbine enthalpy drop, etc [1-4].However, geometrical limitation on the hot side of the heat engine limits ORC efficiency and consequently the amount of energy recovered [511]. The heat pipe can be an innovative approach to this issue as this device with its high thermal conductance can capture waste heat and concentrate it into steam through boiling [3,4].

Several characteristics of heat pipes has been well identified which make them useful in numerous specific applications [11]. These characteristics include, firstly, a closed-loop cycle of operation in which the heat-transfer capacity is several times higher in order of magnitude than the best-known solid conductors [12-15]. This causes the thermal resistance along the heat pipe to be kept to a minimum, and also makes it possible for both of the main segments of the heat pipe (the evaporator and the condenser) to remain physically separate. Secondly, increases in the heat flux in the evaporator lead to an increase in the rate at which the working substance is vaporized, with a relatively small rise in the operating temperature. Consequently, the heat pipe operates under quasi-isothermal conditions, that is to say, the evaporation rate is self-adjusting and able to adapt to a relatively wide range of power inputs, and is also able to maintain an approximately constant source temperature. Thirdly, both segments of the heat pipe operate independently with a common two-phase working substance, thus the area from which the heat is extracted may be of a different size and shape from those of the area from which the heat is dissipated. Hence, high heat fluxes developed over a small area, such as an evaporator surface, may be released over a larger area with a much smaller heat flux, depending on the area ratio. Fourthly, the response time is independent of the distance between the heat source and the heat sink, and it is also less than that required by solid conductors [12-16].

Heat transfer characteristics, isothermal behavior, the ability to maintain an approximately constant evaporator temperature over a range of heat flux levels, and the variability of the evaporator and condenser sizes, are all factors which make heat pipes and thermosyphons effective devices which may be used for many engineering applications $[6,15-18]$.

${ }^{*}$ Corresponding author. Tel.: +962777921663

Fax: +9876543210; E-mail: Saed n 2000@yahoo.com

(C) 2016 International Association for Sharing Knowledge and Sustainability

DOI: $10.5383 /$ ijtee.12.01.006 
However, heat pipes available in industry have several inherent limitations which have prevented their wide spread use. Film boiling and entrainment limitations have been of particular concern [9]. In the last seven years a new version of heat pipes has overcome the limitations of the traditional heat pipes at moderate and high heat fluxes conditions. It utilizes the enhancement in heat transfer and flow pattern characteristics associated with the existence of a vortex promoter in the path of the flow $[16,17]$. The goal of this work is to test the ability of this new heat pipe to capture and concentrate heat from a hot flow of air and quantify the extracted heat as a valuable form of energy.

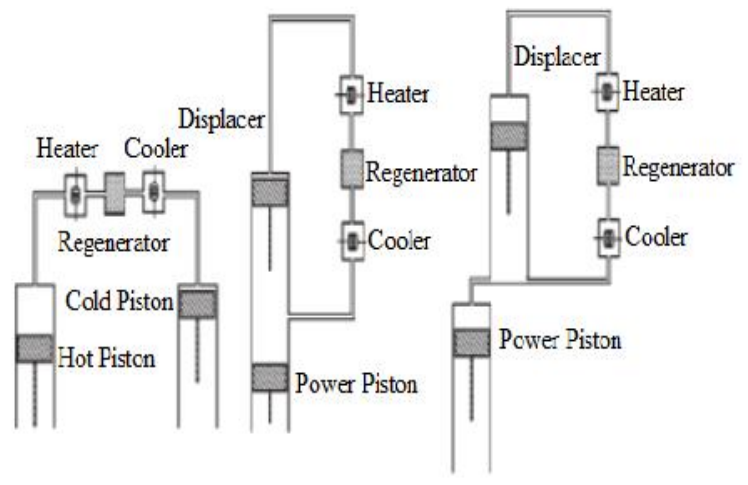

\section{Alpha-Configuration Beta-Configuration Gamma-Configuration}

Fig 1: Three basic mechanical configurations for Stirling engine.

\section{Set-up and procedure}

A stream of hot air was used to simulate the gas steam from which the low grade waste energy is extracted (i.e. $\mathrm{T}<250^{\circ} \mathrm{C}$ ). A blower at a controlled velocity followed by $80 \mathrm{~kW}$ air heater were used. The heater is thermostatically controlled and delivers a stream of air that has a controlled temperature varies between $100^{\circ} \mathrm{C}$ and $300^{\circ} \mathrm{C}$. With this system air velocity varies between $16 \mathrm{~m} / \mathrm{s}$ (maximum) and $4 \mathrm{~m} / \mathrm{s}$ (minimum) Figure (2. a and b). The heater discharges heated air through a flexible stainless steel pipe which leads into the heat pipe tunnel.

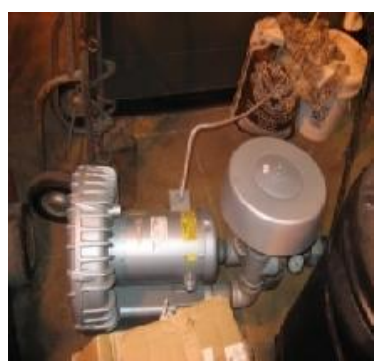

Fig 2 a: Blower used in the project experiments is shown in Figure (3). The laboratory simulator is a unit, designed and built to illustrate the concept of using heat pipes to concentrate waste heat and quantify heat extraction as a function of air temperature and velocity.

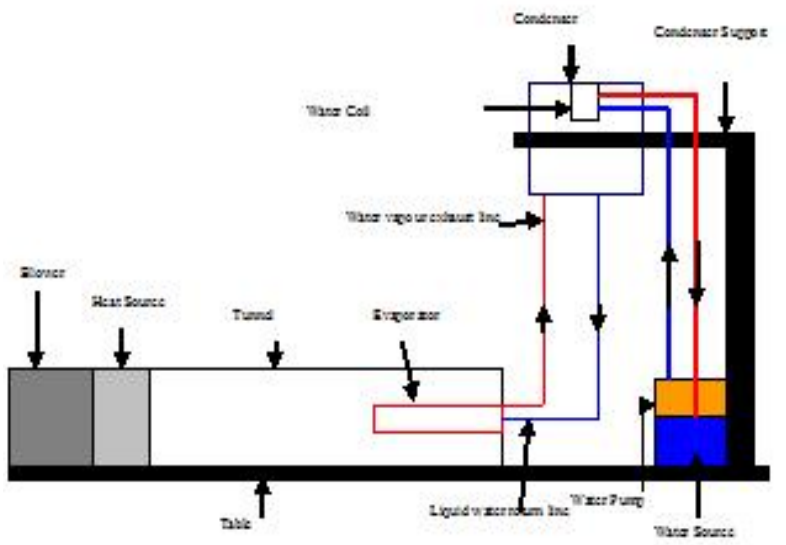

Fig 3: A schematic diagram of a setup used to run the experiments.

Figure (4) shows the layout of evaporator segments inside the testing tunnel. Thermocouples are located on the path of incoming hot air, on the body of the heat pipe, on return and vapor pipes, top and bottom of the condenser and on the path of warm water leaving the system.

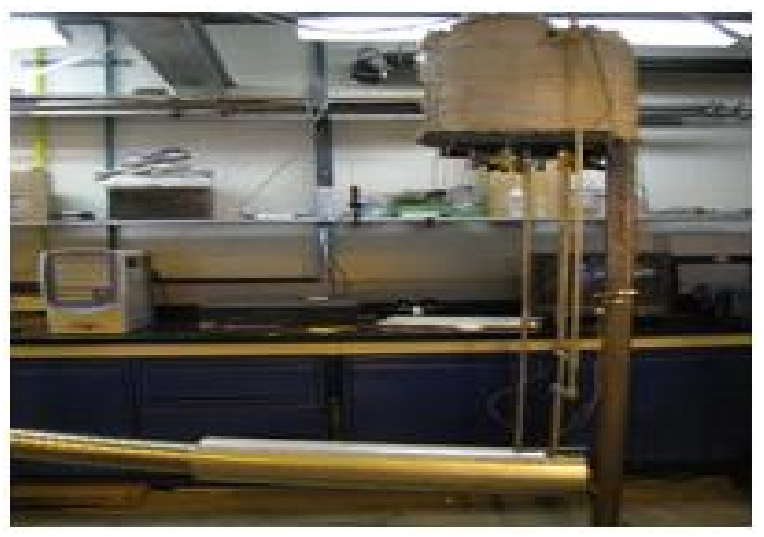

Fig 4: Photograph of the system setup.

The set up consist of a tunnel with an inner diameter of $0.38 \mathrm{~m}$ and annular heat pipe evaporator which was placed within the tunnel. The evaporator had an outer diameter of $0.076 \mathrm{~m}$ and inner diameter of $0.0381 \mathrm{~m}$ with its longitudinal axis overlaps the center of the tunnel. In heat pipe we had two return lines diametrically opposed and a flow modifier (helical coil) as shown in Figure (5). The heat pipe is $0.5 \mathrm{~m}$ in length. The evaporator part of the heat pipe was made of copper of a thermal conductivity of $401 \mathrm{~W} / \mathrm{m} .{ }^{\circ} \mathrm{C}$ at $100{ }^{\circ} \mathrm{C}$, while condenser part was made of stainless steel $304\left(16.2 \mathrm{~W} / \mathrm{m} .{ }^{\circ} \mathrm{C}\right.$ at $\left.100^{\circ} \mathrm{C}\right)$. A stream of cold water was used to extract heat from the condenser part and the temperature of water was measured at both the exit and inlet ports of the condenser. The routine experimental procedure was set up the incoming air velocity into $8 \mathrm{~m} / \mathrm{s}$ or 16 $\mathrm{m} / \mathrm{s}$ and the desired temperature at the heater into $150^{\circ} \mathrm{C}, 200^{\circ}$ $\mathrm{C}$, or $250^{\circ} \mathrm{C}$. Then lab view program was used to record the readings. 


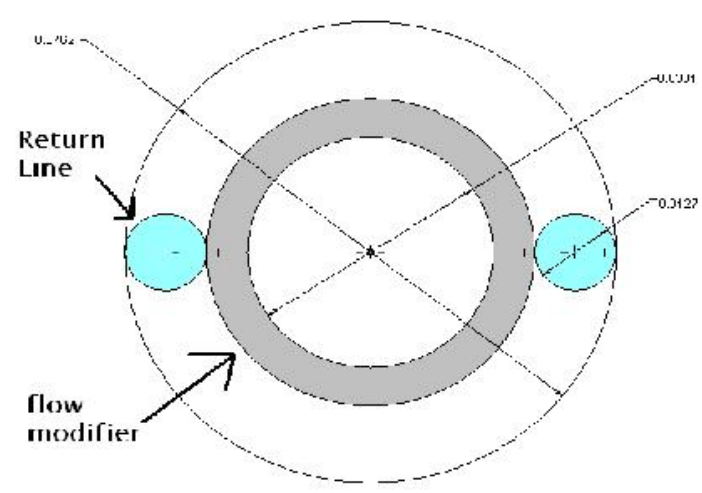

Fig 5: A sketch of evaporator segment.

An early work of our group proves that the existence of the flow modifier inside the evaporator segment enhances the convection heat transfer coefficient inside the evaporator segment of the heat pipe and pushes further the boiling limit regime. Consequently, the heat transferred across the pipe is higher. The key feature of this heat pipe is the flow modifier implemented in the evaporator segment. In its simplest form, this is a helical spring placed inside the evaporator segment to form a helical path for the vaporized water to follow. The existence of the flow modifier inside this section initiates a vortex flow which enhances the heat transfer characteristics across the evaporator walls. It is important to note that the flow modifier parameters depend strongly on the application environment involving the amount of heat flux associated with it [12, 19-20].

The flow inside the evaporator segment of the modified heat pipe is characterized by the following equations [12]:

$$
\begin{aligned}
& N u=0.0586 \operatorname{Re}^{0.8} \operatorname{Pr}^{0.4} \\
& f=0.7866 \operatorname{Re}^{-0.25}
\end{aligned}
$$

The previous work was concerned with extracting heat from moderate and high grade energy source $\left(\mathrm{T}>700^{\circ} \mathrm{C}\right)$. This work concerned with extracting heat from low grade energy source ( $\mathrm{T}$ $<250{ }^{\circ} \mathrm{C}$ ). Tests are conducted to test the effect of the independent parameters on the performance of the recovery system. The independent parameters of concern are : i) the bulk air temperature of the waste heat ii) the bulk velocity of the hot air iii) and the heat pipe operating temperature.

\section{Results and Discussion}

To find out the minimum temperature that the system will stay stable, a test was run with operating conditions denoted by case 1 and shown in table 1 .

Table 1: Cases parameters for the present study.

\begin{tabular}{|l|l|l|l|}
\hline Case Number & $\begin{array}{c}\text { Inflow } \\
\text { Temperature }\end{array}$ & $\begin{array}{c}\text { Inflow } \\
\text { velocity }\end{array}$ & $\begin{array}{c}\text { Water cooling } \\
\text { flow }\end{array}$ \\
\hline 1 & $100^{\circ} \mathrm{C}$ & $8.8 \mathrm{~m} / \mathrm{s}$ & $11 \mathrm{ml} / \mathrm{s}$ \\
\hline 2 & $100^{\circ} \mathrm{C}$ & $8.8 \mathrm{~m} / \mathrm{s}$ & $22 \mathrm{ml} / \mathrm{s}$ \\
\hline 3 & $120^{\circ} \mathrm{C}$ & $9.2 \mathrm{~m} / \mathrm{s}$ & $11 \mathrm{ml} / \mathrm{s}$ \\
\hline 4 & $150^{\circ} \mathrm{C}$ & $10 \mathrm{~m} / \mathrm{s}$ & $11 \mathrm{ml} / \mathrm{s}$ \\
\hline 5 & $150^{\circ} \mathrm{C}$ & $10 \mathrm{~m} / \mathrm{s}$ & $22 \mathrm{ml} / \mathrm{s}$ \\
\hline 6 & $150^{\circ} \mathrm{C}$ & $5 \mathrm{~m} / \mathrm{s}$ & $22 \mathrm{ml} / \mathrm{s}$ \\
\hline
\end{tabular}

The results in Figure 6 clearly show that the system was not operating at a stable condition. The oscillation in the return line shows the periodic increase of heat in return flow (flow in the return pipe). This is due to periodic flow of vapor through the return line instead of flowing through the vapor line to exit the evaporator segment. The oscillations also correspond with overheating the heat pipe (evaporator runs dry). The result shows that the rate of vapor generated in the evaporator is much higher than the rate of condensation in the condenser segment of the heat pipe. At this point another factor comes into the picture: Water cooling flow which is the flow of the cooling agent (water) in the cooling circuit located in the condenser.

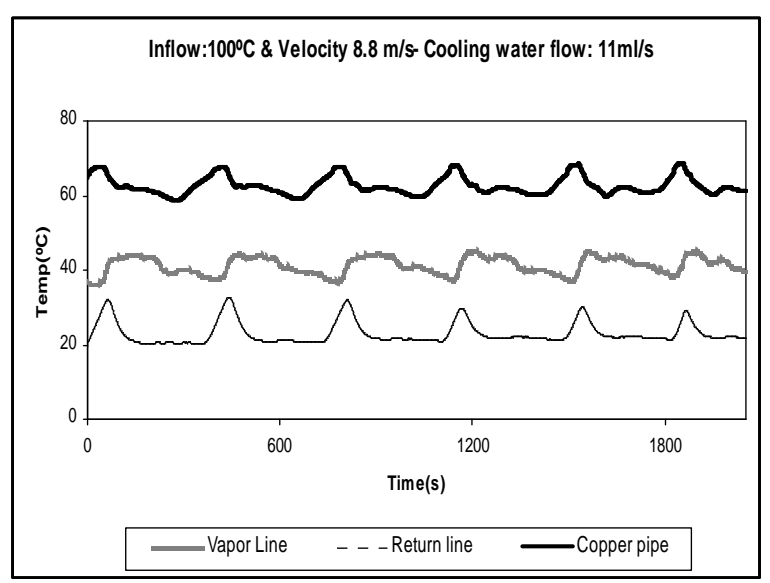

Fig 6: Result of system operation at $100{ }^{\circ} \mathrm{C}$ and $8.8 \mathrm{~m} / \mathrm{s}$ velocity of waste heat and water cooling flow $11 \mathrm{ml} / \mathrm{s}$.

Therefore at the second attempt the rate of water cooling was changed to new operating set of parameters presented in table 1 as case 2. The result of such change is shown in Figure 7. It can be observed that the oscillation in the return line persists even with the decrease in the temperature of the heat pipe. Decreasing the operating temperature of the heat pipe postulates the sonic chock in the vapor line (the vapor velocity reaches 0.3 of sonic flow). Consequently, the heat pipe reaches its extraction limit and any increase of heat over that limit will cause the vapor pressure to build up in the evaporator segment and flows through the return line. Uniform and smooth periodic oscillations on both the return line and the vapor line will be evident. Thus the system at $100^{\circ} \mathrm{C}$ (low grade energy) is not stable.

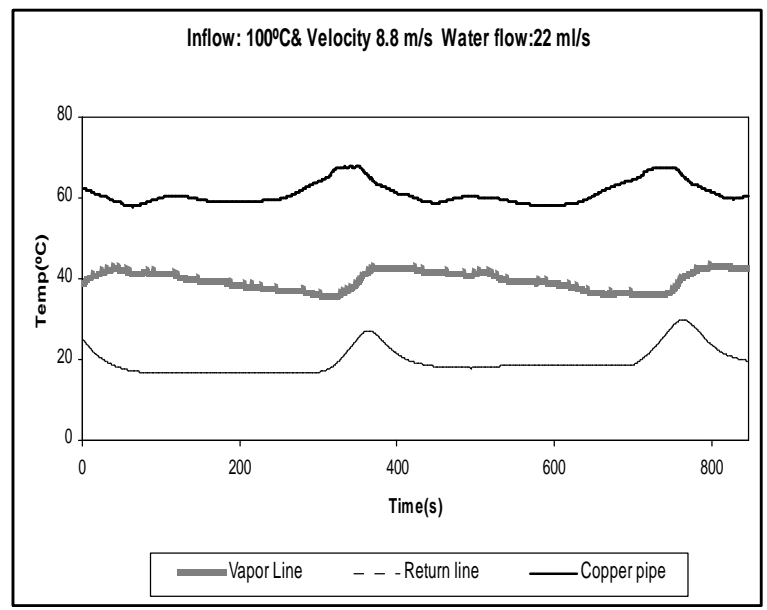

Fig 7: Result of system operation at $100^{\circ} \mathrm{C}$ and $8.8 \mathrm{~m} / \mathrm{s}$ velocity of waste heat and water cooling flow $22 \mathrm{ml} / \mathrm{s}$. 
At this point where the water cooling rate and velocity could not force the system into an operational stage the inflow temperature needs to be increased. The same set of experiments was conducted with $120^{\circ} \mathrm{C}$ inflow hot air temperature (Case 3 in table 1). As one can see in Figure 8 the same sort of instability was observed. This leads the experiment to increase the minimum temperature of inflow hot air to $150^{\circ} \mathrm{C}$.

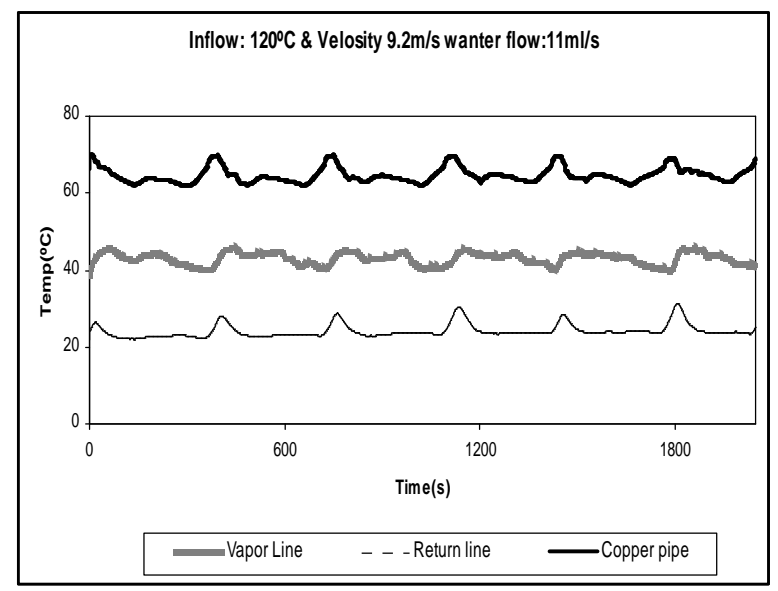

Fig 8: Result of system operation at $120^{\circ} \mathrm{C}$ and $9.2 \mathrm{~m} / \mathrm{s}$ velocity of waste heat and water cooling flow $11 \mathrm{ml} / \mathrm{s}$.

The set up was changed to $150^{\circ} \mathrm{C}$ and the test was re-done with case 4 parameters configuration. The result, Figure 9 , shows stability in the system; thus the minimum operational temperature with the velocity of $10 \mathrm{~m} / \mathrm{s}$ would be $150^{\circ} \mathrm{C}$.

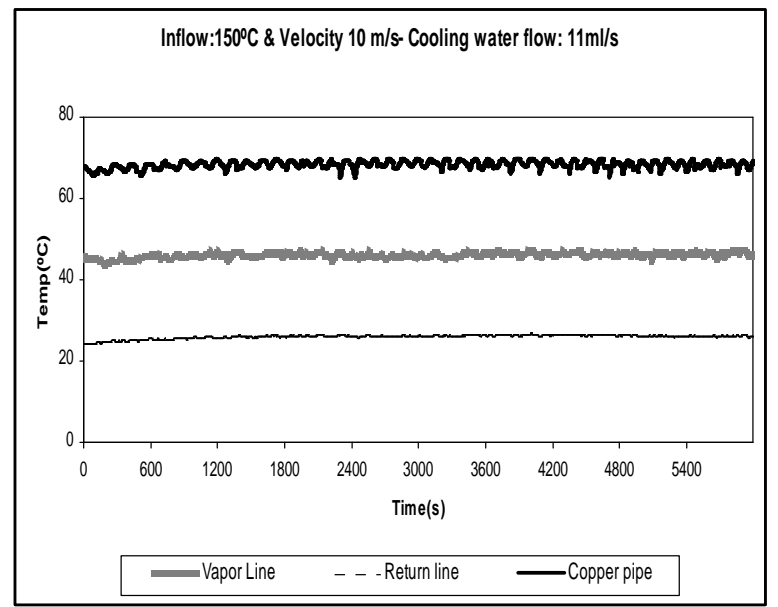

Fig 9: Result of system operation at $150^{\circ} \mathrm{C}$ and $10 \mathrm{~m} / \mathrm{s}$ velocity of waste heat and water cooling flow $11 \mathrm{ml} / \mathrm{s}$.

Even with increasing the rate of cooling water (case 5 in table 1) which will result in the operation of the heat pipe at a lower temperature, the system still showed complete stability. Figure 10 shows the results for operating parameters of case 5 . It is well established that the minimum temperature of waste heat that the system can stay stable and functional is determined to be $150^{\circ} \mathrm{C}$. However the minimum velocity of the incoming hot air also plays an important role. Thus to determine the last boundary of a stable operation, the last factor affecting heat extraction which is the velocity of the incoming hot air flow was decreased to $5 \mathrm{~m} / \mathrm{s}$.

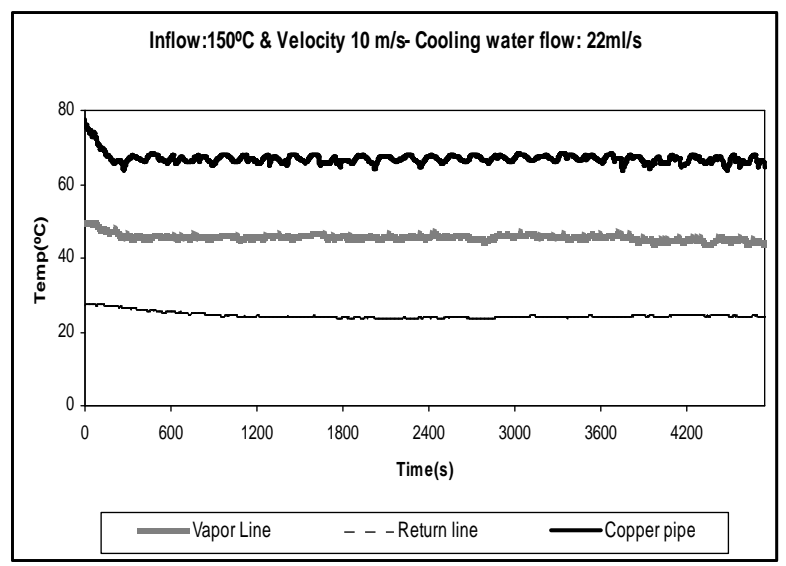

Fig 10: Result of system operation at $150^{\circ} \mathrm{C}$ and $10 \mathrm{~m} / \mathrm{s}$ velocity of waste heat and water cooling flow $22 \mathrm{ml} / \mathrm{s}$.

The last set up before starting the heat extraction is demonstrated by case 6 and shown in table 1 . As it can be observed from the behavior of the system shown in figure 11, the stable operation of the system ceased with decreasing of incoming hot air velocity. This is due to the decrease in heat fluxes to the evaporator and maintaining the same conditions at the condenser segment. This causes a reduction in the heat pipe operating temperature which in role postulates the sonic limitation in the vapor line. This situation emphasizes the important of the cooling cycle characteristics in the condenser segment. Therefore with the $22 \mathrm{ml} / \mathrm{s}$ and $11 \mathrm{ml} / \mathrm{s}$ flow rate in the cooling cycle the minimum operational temperature and velocity combination would be $150^{\circ} \mathrm{C}$ and incoming air flow of $10 \mathrm{~m} / \mathrm{s}$.

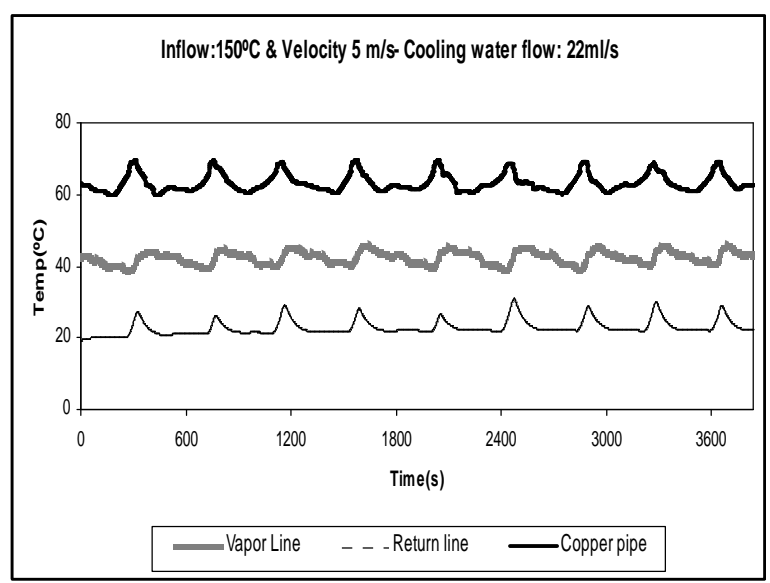

Fig 11: Result of system operation at $150^{\circ} \mathrm{C}$ and $5 \mathrm{~m} / \mathrm{s}$ velocity of waste heat and water cooling flow $22 \mathrm{ml} / \mathrm{s}$.

The amount of heat extracted from the condenser $(Q)$, which is the useful heat supplied by the heat pipe system, is simply quantified by measuring the temperature of the condenser cooling fluid (water) at both inlet and outlet ports.

$$
Q=\dot{m} C_{p} \Delta\left(T_{\text {out }}-T_{\text {in }}\right)
$$




$$
Q^{\prime \prime}=\frac{Q}{A_{e e}}
$$

Where $A_{e e}$ is the effective area of the evaporator segment. This is the area of the evaporator exposed to the hot flow of air assuming that the evaporator wall thickness is small with respect to the diameter of the heat pipe. Whereas $C_{p}$ is the water heat capacity at the average temperature $\left(T_{\text {avg }}=\frac{T_{\text {out }}+T_{i n}}{2}\right)$ and constant pressure.

The results were tabulated and presented in Tables (2):

The change in the hot air velocity is due to the decrease of the air density with increasing air flow temperature. The results presented in table 2 show that the heat extracted rate is almost directly proportional to the temperature of the hot flow.

Table 2: high incoming air flow velocity and $20 \mathrm{~g} / \mathrm{s}$ rate of water cooling flow.

\begin{tabular}{|c|c|c|c|c|c|c|c|c|}
\hline $\begin{array}{c}\mathrm{T}_{\text {hot }} \\
\text { air } \\
{ }^{\circ} \mathrm{C}\end{array}$ & $\begin{array}{c}\mathrm{T} \\
\text { vapor(H } \\
\mathrm{P})\end{array}$ & $\begin{array}{c}\mathrm{T} \\
{ }^{\circ} \mathrm{C} \\
\text { condens } \\
\text { er in }^{\circ} \mathrm{C}\end{array}$ & $\begin{array}{c}\mathrm{V} \\
\text { hot air } \\
\text { veloci } \\
\text { ty } \mathrm{m} / \mathrm{s}\end{array}$ & $\begin{array}{c}\mathrm{q}^{\circ} \text { cooli } \\
\text { ng water } \\
\mathrm{m} / \mathrm{s}\end{array}$ & $\begin{array}{c}\mathrm{T} \\
\text { evaporat } \\
\text { or wall } \\
{ }^{\circ} \mathrm{C}\end{array}$ & $\begin{array}{c}\mathrm{T} \\
\text { condens } \\
\text { er out } \\
{ }^{\circ} \mathrm{C}\end{array}$ & $\begin{array}{c}Q \\
\mathrm{~J} / \mathrm{s}\end{array}$ & $\begin{array}{c}Q^{\prime \prime} \\
\text { kJ/s.m } \\
2\end{array}$ \\
\hline 250 & 57.4 & 3.3 & $\begin{array}{c}12 . \\
3\end{array}$ & 22 & 93.3 & 26.8 & $\begin{array}{c}216 \\
3\end{array}$ & $\begin{array}{c}11.5 \\
7\end{array}$ \\
\hline $\begin{array}{c}207 . \\
9\end{array}$ & 46.6 & 4.8 & $\begin{array}{c}11 . \\
1\end{array}$ & 20 & 74.5 & 24.0 & $\begin{array}{c}184 \\
9\end{array}$ & 8.48 \\
\hline 151 & 48.9 & 4 & 10 & 20 & 59.3 & 18.1 & $\begin{array}{c}118 \\
1\end{array}$ & 6.32 \\
\hline
\end{tabular}

The higher the flow temperature the higher is the heat extracted rate at the condenser associated with higher operating temperature on the heat pipe side. Note that the cooling water parameters at the inlet port of the condenser are almost the same with a tolerated variance (which will slightly affect the outcomes). The cooling water flow rate is about $20 \mathrm{~g} / \mathrm{s}$ and the inlet temperature is about $4{ }^{\circ} \mathrm{C}$. To study the effect of the condenser load on the system, the cooling water flow rate is reduced to about $10.5 \mathrm{~g} / \mathrm{s}$ and the same conditions on the hot flow side were maintained. The results show an increase on the heat pipe operating temperature $\left(23 \%\right.$ at $250{ }^{\circ} \mathrm{C}, 17 \%$ at 200 ${ }^{\circ} \mathrm{C}$, and $5.7 \% 150{ }^{\circ} \mathrm{C}$ ) and a decrease on the rate of heat extracted from the condenser $\left(21 \%\right.$ at $250{ }^{\circ} \mathrm{C}, 13.8 \%$ at $200{ }^{\circ} \mathrm{C}$, and $4 \%$ at $150{ }^{\circ} \mathrm{C}$ ). (Table (3))

Table 3: high incoming air flow velocity and $10.5 \mathrm{~g} / \mathrm{s}$ of water cooling flow rate.

\begin{tabular}{|c|c|c|c|c|c|c|c|}
\hline $\begin{array}{l}\mathrm{T} \\
\text { Waste } \\
\text { Heat } \\
\left({ }^{\circ} \mathrm{C}\right)\end{array}$ & $\begin{array}{c}\mathrm{T} \\
\text { Heat } \\
\text { Pipe } \\
\left({ }^{\circ} \mathrm{C}\right. \\
) \\
\end{array}$ & $\begin{array}{c}\mathrm{T} \\
\text { Water } \\
\text { in } \\
\left({ }^{\circ} \mathrm{C}\right. \\
) \\
\end{array}$ & $\begin{array}{l}\text { Velocit } \\
\text { y }(\mathrm{m} / \mathrm{s})\end{array}$ & $\begin{array}{c}\text { Coolin } \\
\text { g } \\
(\mathrm{ml} / \mathrm{s})\end{array}$ & $\begin{array}{c}\mathrm{T} \\
\text { Water } \\
\text { Out } \\
\left({ }^{\circ} \mathrm{C}\right. \\
) \\
\end{array}$ & $\begin{array}{c}\mathrm{Q} \\
(\mathrm{J} / \mathrm{s})\end{array}$ & $\begin{array}{c}\mathbf{Q}^{\prime \prime} \\
\left(\mathrm{J} / \mathrm{s} \cdot \mathrm{m}^{2}\right. \\
)\end{array}$ \\
\hline $\begin{array}{c}250 . \\
1\end{array}$ & $\begin{array}{c}70 . \\
7 \\
\end{array}$ & 5 & & 11.6 & $\begin{array}{c}39 . \\
7 \\
\end{array}$ & $\begin{array}{c}170 \\
8\end{array}$ & 9137 \\
\hline $\begin{array}{c}200 . \\
8\end{array}$ & $\begin{array}{c}54 . \\
6\end{array}$ & 5.1 & 11.1 & 10.5 & $\begin{array}{c}36 . \\
2\end{array}$ & $\begin{array}{c}136 \\
7\end{array}$ & 7312 \\
\hline $\begin{array}{c}150 . \\
9\end{array}$ & $\begin{array}{c}51 . \\
7\end{array}$ & 5.7 & 10 & 10.0 & $\begin{array}{c}32 . \\
6\end{array}$ & $\begin{array}{c}113 \\
6\end{array}$ & 6078 \\
\hline
\end{tabular}

The preceding results show that with increase of cooling water flow rate the temperature of the heat pipe decreases and the heat flow increases. With the increase in cooling water by $10 \mathrm{ml} / \mathrm{s}$ the heat pipe temperature decreases by $13.3^{\circ} \mathrm{C}$ and the heat flow rate increases by $454.3 \mathrm{~J} / \mathrm{s}$. Thus hypothetically by increasing the incoming cooling water flow rate by 3 units ( 30 $\mathrm{ml} / \mathrm{s})$ and consequently decreasing the heat pipe temperature by 3 units $\left(3 \times 13.3=39.9^{\circ} \mathrm{C}\right)$, the heat pipe could extract: $454.3 \times 3$ (units) $+1708=3070.9 \mathrm{~J} / \mathrm{s}$

Which means the heat pipe under experiment can extract maximum $3 \mathrm{~kW}$ of heat with the waste heat of $250^{\circ} \mathrm{C}$ and hot air velocity of $12.3 \mathrm{~m} / \mathrm{s}$.

The same calculation can be done for incoming air flow of $200^{\circ} \mathrm{C}$ and $150^{\circ} \mathrm{C}$ and different incoming air velocities. For a waste heat temperature of $200{ }^{\circ} \mathrm{C}$ and hot air velocity of $11.1 \mathrm{~m} / \mathrm{s}$, a maximum of $1.9 \mathrm{~kW}$ heat can be extracted. Whereas, for waste heat of $150{ }^{\circ} \mathrm{C}$ and hot air velocity of $10 \mathrm{~m} / \mathrm{s}$, the maximum heat that can be extracted would be approximately $1.5 \mathrm{~kW}$.

Also it has been noticed that the temperature of the evaporator surface doesn't affect much with the heating load at the condenser side and it is mainly a function of the hot flow characteristics. Since, the convection heat transfer coefficient at the inner side of the evaporator is much higher that at the hot flow side.

Table 4: Results at low incoming air flow velocity and high rate of water cooling flow.

\begin{tabular}{|c|c|c|c|c|c|c|c|}
\hline $\begin{array}{l}\mathrm{T} \\
\text { Waste } \\
\text { Heat } \\
\left({ }^{\circ} \mathrm{C}\right)\end{array}$ & $\begin{array}{l}\mathrm{T} \\
\text { Heat } \\
\text { Pipe } \\
\left({ }^{\circ} \mathrm{C}\right. \\
)\end{array}$ & $\begin{array}{l}\mathrm{T} \\
\text { Water } \\
\text { in } \\
\left({ }^{\circ} \mathrm{C}\right. \\
)\end{array}$ & $\begin{array}{l}\text { Velocit } \\
\text { y }(\mathrm{m} / \mathrm{s})\end{array}$ & $\begin{array}{l}\text { Coolin } \\
\mathrm{g} \\
(\mathrm{ml} / \mathrm{s})\end{array}$ & $\begin{array}{l}\mathrm{T} \\
\text { Water } \\
\text { Out } \\
\left({ }^{\circ} \mathrm{C}\right. \\
)\end{array}$ & $\begin{array}{l}\mathrm{Q} \\
(\mathrm{J} / \mathrm{s})\end{array}$ & $\begin{array}{l}\mathbf{Q}^{\prime \prime} \\
\left(\mathrm{J} / \mathrm{s} \cdot \mathrm{m}^{2}\right. \\
)\end{array}$ \\
\hline 250 & $\begin{array}{l}51 . \\
5 \\
\end{array}$ & 6.1 & 5 & 22 & $\begin{array}{l}22 . \\
7 \\
\end{array}$ & $\begin{array}{l}162 \\
9 \\
\end{array}$ & 8715 \\
\hline $\begin{array}{l}200 . \\
6\end{array}$ & $\begin{array}{l}49 . \\
7\end{array}$ & 8.3 & 6.2 & 21 & $\begin{array}{l}22 . \\
7\end{array}$ & $\begin{array}{l}126 \\
2 \\
\end{array}$ & 6750 \\
\hline
\end{tabular}

For better understand of this case we reduced the heat transfer coefficient at the outer side of the evaporator by reducing the velocity of the hot air flow to $5 \mathrm{~m} / \mathrm{s}$ and $6 \mathrm{~m} / \mathrm{s}$. The results are shown in table 4 and 5 . The evaporator wall temperature decreases by $3{ }^{\circ} \mathrm{C}$ with doubling the cooling load at the condenser $(10 \mathrm{~g} / \mathrm{s}$ to $20 \mathrm{~g} / \mathrm{s})$.

Table 5: Results at low incoming air flow velocity and low rate of water cooling flow.

\begin{tabular}{|c|c|c|c|c|c|c|c|}
\hline $\begin{array}{c}\mathrm{T} \\
\text { Waste } \\
\text { Heat } \\
\left({ }^{\circ} \mathrm{C}\right)\end{array}$ & $\begin{array}{c}\mathrm{T} \\
\text { Heat } \\
\text { Pipe } \\
\left({ }^{\circ} \mathrm{C}\right. \\
)\end{array}$ & $\begin{array}{c}\mathrm{T} \\
\text { Water } \\
\text { in } \\
\left({ }^{\circ} \mathrm{C}\right. \\
)\end{array}$ & $\begin{array}{l}\text { Velocit } \\
\text { y (m/s) }\end{array}$ & $\underset{(\mathrm{ml} / \mathrm{s})}{\text { Coolin }}$ & $\begin{array}{c}\mathrm{T} \\
\text { Water } \\
\text { Out } \\
\left({ }^{\circ} \mathrm{C}\right. \\
\text { ) }\end{array}$ & $\begin{array}{c}\mathrm{Q} \\
(\mathrm{J} / \mathrm{s})\end{array}$ & $\begin{array}{c}\mathbf{Q}^{\prime \prime} \\
\left(\mathrm{J} / \mathrm{s} \cdot \mathrm{m}^{2}\right. \\
)\end{array}$ \\
\hline $\begin{array}{c}247 . \\
2\end{array}$ & $\begin{array}{c}57 . \\
7 \\
\end{array}$ & 7.2 & 5.6 & 10 & $\begin{array}{c}44 . \\
1 \\
\end{array}$ & $\begin{array}{c}154 \\
6\end{array}$ & 8268 \\
\hline $\begin{array}{c}200 . \\
9\end{array}$ & $\begin{array}{c}52 . \\
7\end{array}$ & 6 & 6.2 & 9.5 & 36 & $\begin{array}{c}119 \\
3\end{array}$ & 6380 \\
\hline
\end{tabular}

Figure (12) shows a comparison of the amount of the heat extracted at different combination of hot air temperature, hot air velocity and cooling water rate. 


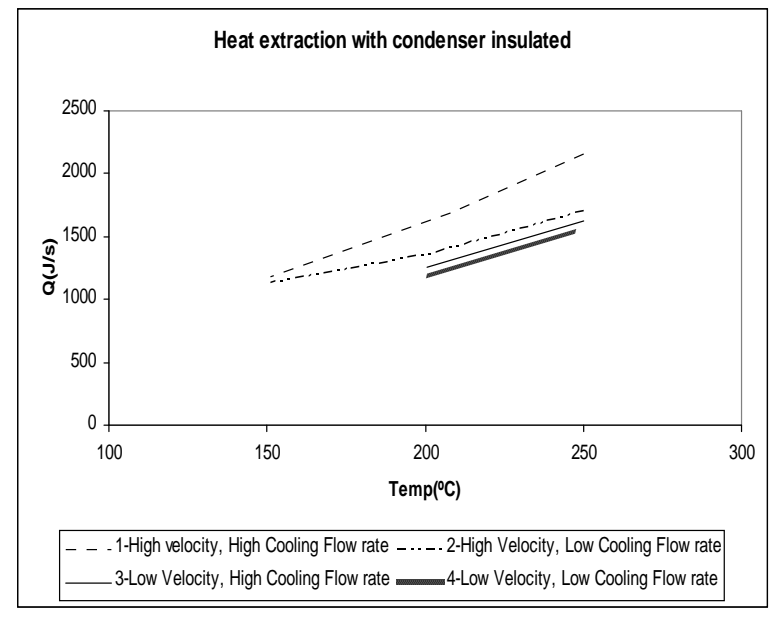

Fig 12: Heat extracted at different conditions.

The results show that as the hot air velocity increases the amount of heat extracted increases. Also, the increase on the cooling load at the condenser increase the amount of heat extracted and decreases the operating temperature of the evaporator. The operating temperature of the evaporator limits the amount of heat extracted from this system. The lower the operating temperature the closer the system to sonic chock limitation (i.e. the velocity of the working fluid inside the evaporator is about 0.3 of the sonic velocity).

\section{Conclusion}

A new system for heat recovery from low grade energy has been built and tested. A single heat pipe used in this research was able to extract $2 \mathrm{~kW}$ of energy from waste heat of $250^{\circ} \mathrm{C}$. However a heat pipe can extract $11.5 \mathrm{~kW} / \mathrm{m}^{2}$ heat fluxes. The maximum energy extraction by such system from low grade energy can be up to $3 \mathrm{~kW}$. While a heat pipe regardless of its size can have heat flux up to $16.5 \mathrm{~kW} / \mathrm{m}^{2}$ from waste heat flow at $250^{\circ} \mathrm{C}$ and 12.3 $\mathrm{m} / \mathrm{s}$ velocity. Also, the system can extract about $1 \mathrm{~kW}$ heat or $6.5 \mathrm{~kW} / \mathrm{m}^{2}$ heat flux at temperatures as low as $150^{\circ} \mathrm{C}$. This can be useful in using series of heat pipes in a way that the waste heat goes through stages of reduction of temperature while the first series extracts the highest and the subsequent series operate as if the initial temperature introduced to them was lower. However, this system has limitations. The heat pipe under $150^{\circ} \mathrm{C}$ is not functional properly (doesn't have a steady state behavior) and around that temperature is highly affected by the velocity of the waste heat.

\section{References}

[1] W. Tianyou, Z. Yajun, P. Zhijun, S. Gequn, A review of researches on thermal exhaust heat recovery with Rankine cycle, Renewable and Sustainable Energy Reviews. 15 (2011) 2862-2871.

[2] J.P. Roy, M.K. Mishra, M. Ashok, Parametric optimization and performance analysis of a waste heat recovery system using Organic Rankine Cycle, Energy. 35 (2010) 5049-5062.
[3] Tlili I., Sa'ed A. Musmar, 'Thermodynamic evaluation of a second order simulation for Yoke Ross Stirling engine' Energy Conversion and Management, Volume 68, April 2013, Pages 149-160.

[4] Tlili I., Sa'ed A. Musmar, 'Numerical Investigation of Working Fluid Effect on Stirling Engine Performance', Int. J. of Thermal \& Environmental Engineering, 10, 2015, 31-36

[5] High COP Heat Pump System, MTI Technical Report to U.S. DOE, HCP/M5056-01, April (1979).

[6] W. Srimuang, P. Amatachaya, A review of the applications of heat pipe heat exchangers for heat recovery, Renewable and Sustainable Energy Reviews. 16 (2012) 4303-4315.

[7] W. Nowak, A. Borsukiewicz-Gozdur, A.A. Stachel, Using the low temperature Clausius-Rankine cycle to cool technical equipment, Applied Energy. 85 (2008) $582-588$.

[8] T.C. Hung, Waste-heat recovery of organic rankine cycle using dry fluids, Energy Convers Manage. 42 (2001) 539-53.

[9] Sa'ed A Musmar, AT Al-Halhouli, Iskander Tlili, S. Buttgenbach. 'Performance Analysis of New Water Based Micro-Cooling System, Experimental Heat Transfer, DOI:10.1080/08916152.2015.1024353, 2015.

[10] O. Badr, P.W. O'Callaghan, S.D. Probert, Rankine-cycle systems for harnessing power from low-grade energy sources, Appl Energy. 36 (1990) 263-92.

[11] B.T. Liu, K.H. Chien, C.C. Wang, Effect of working fluids on organic Rankine cycle for waste-heat recovery, Energy. 29 (2004) 1207-1217.

[12] S.A. Musmar, In-situ Thermal Analysis Probe, Ph.D Thesis, Mining and Materials Department, McGill University, Montreal, Canada; 2006.

[13] G.Y. Eastman, The Heat Pipe, Scientific American. 218 (1968) $38-46$

[14] G.Peterson, An Introduction to Heat Pipes Modeling, Testing, and Applications, John Wiley \& sons, Inc., New York, NY, USA; 1994

[15] S. Chi, Heat Pipe Theory and Practice, Hemisphere Publishing Corporation, Washington, USA; 1976.

[16] [16] P. Dunn, D. Reay, Heat Pipes, Third Edition, Pergamon Press, UK; 1982.

[17] A. Faghri, Heat Pipe Science and Technology, Taylor \& Francis, Washington D.C., 1995.

[18] W. Ying-Che, C. Hung-Pin, C. Chih-Chung, C. Chang$\mathrm{Li}$, Heat pipe with PCM for electronic cooling, Applied Energy 88 (2011) 1825-1833.

[19] [19] E. Martin, A. Velazquez, Effect of span length and temperature on the 3-D confined flow around a vortex promoter, International Journal of Heat and Fluid Flow. 32 (2011) 1173-1185.

[20] M. Meis, F. Varas, A. Velázquez, J.M. Vega, Heat transfer enhancement in micro-channels caused by vortex promoters, International Journal of Heat and Mass Transfer. 53 (2010) 29-40. 